
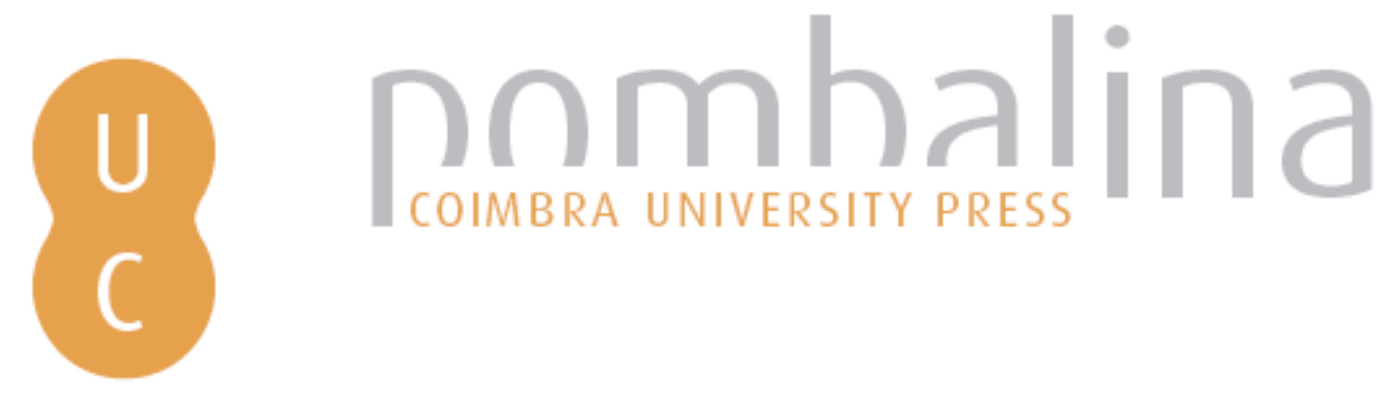

\title{
O Estado Novo na historiografia portuguesa: sobre a questão do Fascismo
}
Autor(es):
Martinho, Francisco Carlos Palomanes
Publicado por: Imprensa da Universidade de Coimbra
URL
persistente:
URI:http://hdl.handle.net/10316.2/38576
DOI:
DOI:http://dx.doi.org/10.14195/978-989-26-0646-0_5

Accessed : $\quad$ 26-Apr-2023 01:28:36

A navegação consulta e descarregamento dos títulos inseridos nas Bibliotecas Digitais UC Digitalis, UC Pombalina e UC Impactum, pressupõem a aceitação plena e sem reservas dos Termos e Condições de Uso destas Bibliotecas Digitais, disponíveis em https://digitalis.uc.pt/pt-pt/termos.

Conforme exposto nos referidos Termos e Condições de Uso, o descarregamento de títulos de acesso restrito requer uma licença válida de autorização devendo o utilizador aceder ao(s) documento(s) a partir de um endereço de IP da instituição detentora da supramencionada licença.

Ao utilizador é apenas permitido o descarregamento para uso pessoal, pelo que o emprego do(s) título(s) descarregado(s) para outro fim, designadamente comercial, carece de autorização do respetivo autor ou editor da obra.

Na medida em que todas as obras da UC Digitalis se encontram protegidas pelo Código do Direito de Autor e Direitos Conexos e demais legislação aplicável, toda a cópia, parcial ou total, deste documento, nos casos em que é legalmente admitida, deverá conter ou fazer-se acompanhar por este aviso.

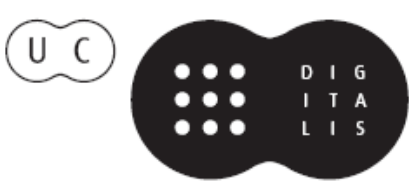




\title{
O ESTAdo NOVO NA Historiografia PORTUGUESA: SOBRE A QUESTÃO DO FASCISMO
}

\author{
Francisco Carlos Palomanes martinho \\ Departamento de História da USP - Pesquisador do CNPQ
}

\section{Introdução}

"Ainda não houve nenhum regime tão parecido com o italiano como o nosso"1. Com essas palavras, Manuel de Lucena, em seu clássico estudo sobre o Estado $\mathrm{Novo}^{2}$, afirma peremptoriamente a natureza fascista do regime autoritário instaurado em Portugal a partir do golpe de Estado de 28 de maio de 1926. Não foi Lucena o primeiro autor a abordar o tema. Mas seu estudo foi, por certo, o que balizou a maior parte das análises seguintes

\footnotetext{
${ }^{1}$ LUCENA, Manuel de. A evolução do sistema corporativo português. Volume I: O Salazarismo. Lisboa, Perspectivas e realidades, 1976, p. 38.

2 Estado Novo português: Inaugurado a partir da aprovação da Constituição Corporativa de 1933 como consequência do processo de transição da ditadura militar para uma ditadura civil sob a liderança de António Oliveira Salazar. O então ministro das Finanças é empossado Presidente do Ministério em 5 de julho de 1932, cargo que muda de nome para Presidente do Conselho de Ministros na Constituição. Manteve-se ditador até setembro de 1968 quando, por motivo de doença, foi substituído por Marcello Caetano. Além da Constituição foi aprovado na mesma ocasião o Acto Colonial. O regime corporativo português manteve-se com pequenas alterações legislativas até a Revolução dos Cravos em 1974. Sobre as periodicidades do Estado Novo, ver: CRUZ, Manuel Braga da. O partido e o Estado no salazarismo. Lisboa: Editorial Presença, 1988; ROSAS, Fernando. Salazar e o salazarismo: um caso de longevidade política. In: ROSAS, Fernando \& BRITO, José Maria Brandão de (Organizadores). Salazar e o salazarismo. Lisboa: Publicações D. Quixote, 1989, p. 13-31; TORGAL, Luís Reis. Estado Novo e "Fascismo". In: Estados Novos Estado Novo. Coimbra: Imprensa Universidade de Coimbra, 2009, p. 289-367.
} 
sobre o corporativismo português. Trata-se de um trabalho escrito em 1971, na França, mas que veio a ser publicado apenas a seguir à Revolução dos Cravos de 25 de Abril de 1974. É, pois, digno de nota, que apenas entre finais da década de 1960 e, sobretudo, a partir do início da década seguinte, o regime autoritário português, ainda antes de sua queda, começou a ser analisado de forma sistemática e a partir de certo rigor acadêmico. Foram nesses anos que a preocupação de um entendimento do Estado Novo de forma objetiva, longe da pecha ideológica ou pejorativa, como alerta Reis Torgal ${ }^{3}$, começou a ser utilizada para o regime governado primeiro por Oliveira Salazar e a seguir por Marcello Caetano.

Os debates acadêmicos, principalmente a seguir à transição democrática portuguesa, em parte se confundiram com ações governamentais, até por que muitos dos intelectuais que estudavam o Estado Novo tinham também militância política e se encontravam comprometidos com a construção da democracia portuguesa. O governo pós-revolucionário, sob os auspícios da Presidência do Conselho de Ministros publicou uma série de documentos organizados a partir de uma comissão denominada Comissão do Livro Negro sobre o Regime Fascista ${ }^{4}$. Em 1980, um Colóquio organizado na Faculdade de Letras da Universidade de Lisboa, cujas "Actas" foram publicadas dois anos depois, tinha como título O fascismo em Portugal ${ }^{5}$. Nos dois casos os esforços para equivaler o Estado Novo e os fascismos, em particular o italiano, ficam evidentes. Não que sejam exatamente qualificações empobrecedoras e vulgarizadoras do fascismo. Estas, sobretudo aqui, estão longe de nossas preocupações. Mas é interessante notar a tendência inicial a meu ver predominante para o "ser fascista" entre os analistas da ditadura portuguesa. Posteriormente novos estudos, conforme veremos, foram sofisticando e problematizando mais

3 TORGAL, Luís Reis. Estado Novo e "Fascismo". In: Obra citada, p. 332.

4 Comissão criada pelo Decreto-lei $n^{\circ} 110 / 78$. Foram publicados dezenas de livros com temas específicos, dentre os quais se destacam: Eleições do Regime Fascista, 1979; A Política de Informação no Regime Fascista, 1980; A Política de Informação no Regime Fascista II, 1980; Presos Políticos no Regime Fascista, I, II, III e IV, 1981-1985; Discriminação Política no Emprego no Regime Fascista, 1982; Trabalho, Sindicatos e Graves no Regime Fascista.

5 VVAA. O fascismo em Portugal. Actas do Colóquio realizado na Faculdade de Letras de Lisboa em Março de 1980. Lisboa: A Regra do Jogo, 1982. 
o tema, de modo que o entendimento do Estado Novo como fascista foi, ainda que não exatamente abandonado, ao menos relativizado.

O que pretendo apresentar, sem naturalmente esgotar o tema, é um breve balanço de algumas das principais linhas de interpretação sobre o Estado Novo produzidas por historiadores e/ou cientistas sociais portugueses a partir da última fase do regime autoritário, iniciada a partir da posse de Marcello Caetano na presidência do Conselho de Ministros. O debate estará centrado em alguns temas que, a meu ver, facilitam o diálogo a respeito da maior ou menor proximidade do Estado Novo com os fascismos: 1. o processo de institucionalização da ditadura; 2. o papel do partido político; 3. a relação estabelecida pelo Estado Novo com a tradição e a modernidade; 4. por fim, a questão da continuidade do Estado Novo no pós-guerra, acontecimento que, ao lado da vizinha Espanha, constitui um fato singular nos regimes corporativos estabelecidos nos anos 1920 e 1930.

\section{Questões preliminares: fascismo, conservadorismo, reação e regime político}

Os debates a respeito do fascismo são controversos e partem de opções teóricas, metodológicas e mesmo ideológicas bastante distintas. Interpretações que, inevitavelmente, levam a conclusões diferenciadas, sempre de acordo com o manancial de fontes e referências utilizadas. Como afirmou Edda Saccomani, as interpretações a respeito do fascismo são tão diversas que chegam, por vezes, às raias da contradição ${ }^{6}$.

Pertenço ao campo de estudiosos que considera o fascismo um fenômeno próprio das sociedades liberais em crise e que, portanto, não pode nem deve ser entendido de forma estática, limitando-se ou bem à leitura dos seus movimentos iniciais ou bem dos regimes estabelecidos. Trata-se, assim, de uma perspectiva que o vê em um sentido amplo: surgimento, crescimento e

${ }^{6}$ SACCOMANI, Edda. Fascismo. In: BOBBIO, Norberto; MATEUCCI, Nicola; PASQUINO, Gianfranco. Dicionário de Política. $4^{a}$ edição. Brasília, DF: Editora Universidade de Brasília, 1992, p. 446. 
tomada de poder ${ }^{7}$. Para compreendê-lo em sua complexidade deve-se considerar as diferenças de cada etapa ao mesmo tempo em que é necessário levar em conta com a mesma equivalência os momentos iniciais e finais do fascismo. Pontos de unidade, entretanto, mantêm-se ao longo de todo o período: uma ideia de regeneração societária, a energização das massas e a purificação da $\mathrm{Nação}^{8}$. Esses pontos de unidade se expressam em um esforço de institucionalização que apontam para um sistema autoritário, de monopolização da política através de um partido único, de massas e com uma ideologia fundada no culto ao Chefe' . Por fim, ainda que por limitação de espaço e foco de análise não vá tratar do tema, considero que a insurgência de movimentos neofascistas principalmente a partir da década de 1980 impõe a revisão das teses que restringem o fascismo à circunstância da crise do entreguerras ${ }^{10}$.

Muitos desses pontos são semelhantes às características de outras ditaduras e esta talvez seja uma das razões que fazem com que o termo fascismo seja utilizado para identificar sistemas políticos com elevado grau de distinção. Como disse Robert Paxton, existem de fato fronteiras sutis entre o fascismo e outros modelos autoritários, sobretudo aqueles datados das décadas de 1920 e 1930, quando diversos regimes antidemocráticos em geral assumiram alguma encenação fascista ${ }^{11}$. E mais, para o caso que aqui nos interessa, adverte que não devemos utilizar o termo fascismo para ditaduras pré-democráticas. Falta-lhes "a manipulação do entusiasmo das massas e a energia demoníaca do fascismo"12.

Outra rápida questão diz respeito à necessidade, a meu ver premente, de inserção no debate dos conceitos de conservadorismo e reacionarismo. É que

7 PAXTON, Robert. A anatomia do fascismo. São Paulo: Paz e Terra, 2007, p. 335. Nesta linha de interpretação encontram-se também os trabalhos de STERNHELL, Zeev; SZNAJDER, Mario; \& ASHÉRI, Maïa. Nascimento da ideologia fascista. Venda Nova: Bertrand, 1995 e TEIXEIRA DA SILVA, Francisco Carlos. Os fascismos. In: REIS FILHO, Daniel Aarão; FERREIRA, Jorge; ZENHA, Celeste. O Século XX. Volume 2: O tempo das crises: Revoluções, fascismos e guerras. Rio de Janeiro: Civilização Brasileira, 2000, p. 109-164.

8 PAXTON, Robert. A anatomia do fascismo. Obra citada, p. 335-336.

9 SACCOMANI, Edda. Fascismo. Obra citada, p. 466.

10 TEIXEIRA DA SILVA, Francisco Carlos. Os fascismo. Obra citada, p. 113-115.

11 PAXTON, Robert. A anatomia do fascismo. Obra citada, 355-356.

12 Idem, 354. 
talvez eles sirvam melhor para o entendimento de algumas ditaduras europeias dos anos 1930, como por exemplo a do Estado Novo. Explico: como disse Eric Hobsbawm, os fascistas foram os "revolucionários da contrarrevolução"13. Diz assim o historiador inglês por que originalmente o fascismo se apresentou como um movimento de ruptura frente às elites tradicionais, com suas formas de organização política e com seus valores. Ao mesmo tempo, o compromisso com a modernidade era uma de suas principais características. É neste sentido que Mussolini desafiou a existência de Deus rogando que um raio o abatesse caso Ele de fato existisse.. Anos depois, o futurista Filippo Marinetti afirmava: "Um carro em velocidade é mais belo que a Vitória de Samotrácia"14. Exemplos, portanto, não faltam para evidenciar a relação fascismo/modernidade bem como o ódio e o desprezo para com a tradição.

Por outro lado, os evidentes compromissos com a modernidade e o progresso não ofuscam o vínculo, igualmente simbiótico, dos fascismos com certa perspectiva tradicionalista. Referências constantes a um passado perfeito, de um povo bom e heroico que se vê momentaneamente contaminado por valores exógenos são perceptíveis no fascismo desde as suas origens. A própria escolha do feixe (o fascio) como representação simbólica do primeiro fascismo, o italiano, é a evidente expressão do culto a um passado mítico ${ }^{15}$. Ainda de acordo com Paxton, enquanto que os primeiros movimentos fascistas exploraram os protestos das vítimas da industrialização, quando da chegada ao poder adotaram o caminho da concentração e da prosperidade industrial, voltada principalmente para a guerra. ${ }^{16}$

O fascismo é pois, para mim, um movimento propositadamente ambíguo: moderno e revolucionário que se opõe tanto à revolução bolchevique quanto ao conservadorismo das antigas elites dominantes. Ainda que com estas venha a compor no momento de sua consolidação, sua perspectiva de progresso e de modernidade não se apaga; tradicionalista e conservador, que combate

\footnotetext{
${ }^{13}$ HOBSBAWM, Eric. A queda do liberalismo. A era dos extremos. O breve século XX (19141991). São Paulo: Companhia das Letras, 1005, p. 113-143.

${ }^{14}$ Citado por PAXTON, Robert. A anatomia do fascismo... p. 18.

15 Os fasci são insígnias do fascismo originárias do Império Romano. Ver: TRENTO, Angelo. Fascismo Italiano. São Paulo: Ática, 1986.

${ }^{16}$ PAXTON, Robert. A anatomia do fascismo. Obra citada, p. 31.
} 
os valores degenerativos da sociedade liberal e constrói o Estado a partir da ideia de comunidade ${ }^{17}$.

Voltemos então aos conservadores e reacionários.

Para Tiziano Bonazzi, o conservadorismo nasce com o processo de laicização do pensamento europeu que transformou a ação política em instrumento transformador do homem. Trata-se de um movimento reativo contra a autonomia da Razão, sobretudo da perspectiva que fazia dela, a Razão, a medida do Real. A tese conservadora considera a natureza humana não mutável pela ação prática, na medida em que mergulha suas raízes em uma realidade sobre-humana: a vontade divina. Assim, nem o conhecimento nem a ação política poderiam ser vistos como totalmente libertadores. Para os conservadores, a negação da autonomia histórica dos indivíduos não é incompatível com a ideia de progresso, desde que este seja visto como um fenômeno evolutivo, natural e não arbitrado pelo indivíduo. No campo político propriamente dito, duas questões parecem relevantes: em primeiro lugar, o conservadorismo se manifesta no sentido da preservação do poder e contra a sua redução a interesses egoístas; em segundo lugar, a entrada das massas na cena política constituiu o principal pesadelo do pensamento conservador ${ }^{18}$.

Outra interpretação, em parte alternativa à de Bonazzi, entende o conservadorismo como um elemento, ainda que oposto à emergência da democracia e do liberalismo, pertencente ao campo da Razão. Não por acaso, importantes representantes do pensamento conservador, como Burke, Gentz ou Ranke, têm preocupações com o método e o compromisso com o saber plenamente identificado com a tradição Iluminista. Longe do compromisso com o retorno ao passado, defendem um projeto alternativo tanto em relação ao Antigo Regime como em relação ao sufrágio universal. Nas palavras de Burke: "nem tirania do rei, nem tirania do povo" 19.

17 TEIXEIRA DA SILVA, Francisco Carlos. Os fascismos.

${ }^{18}$ BONAZZI, Tiziano. Conservadorismo. In: Dicionário de Política. Obra citada, 1992, 242246.

19 TEIXEIRA DA SILVA, Francisco Carlos. Introdução. In: TEIXEIRA DA SILVA, Francisco Carlos; MEDEIROS, Sabrina Evangelista; VIANNA, Alexander Martins. Dicionário crítico do pensamento da direita: Ideias, Instituições e Personagens. Rio de Janeiro: Mauad/FAPERJ, 2000, p. 11-21. 
Ainda que sejam evidentes os pontos de unidade, ser conservador não é o mesmo que ser reacionário. Como afirmei, o conservadorismo aceita, ainda que com pressupostos próprios, a ideia de progresso. O reacionário é aquele que, de forma talvez um pouco simplificada, tenta regredir a sociedade para estágios pretéritos, considerados ideais e, em larga medida, mitificados. O impulso reacionário tem suas origens na luta pela preservação dos privilégios (no sentido original do termo, de leis privadas) caros ao Antigo Regime ${ }^{20}$. Neste sentido o pensamento típico da reação é aquele que projeta o retorno a um passado, que tem seu olhar utópico diante de um espelho.

É interessante notar, ainda à guiza de um entendimento preliminar dos temas tratados, que quando nos referimos ao Estado Novo estamos a falar regime político, que não é o mesmo que governo, sistema político ou sistema econômico. Para a tradição da ciência política, o regime político deve ser entendido como "o conjunto de instituições que regulam a luta pelo poder e o seu exercício, bem como a prática dos valores que animam tais instituições" 21 . Não bastaria, então, a existência de instituições de tipo fascista; teríamos que perceber a prática que anima seu funcionamento.

\section{As teses fundadoras...}

Os primeiros trabalhos de natureza acadêmica a respeito do Estado Novo foram produzidos por Hermínio Martins entre 1968 e 1971. Como disse Maria de Fátima Bonifácio, a análise apresentada por Martins dá-nos "uma pista de inquérito inteiramente distinta por sua originalidade e sofisticação"22. A originalidade apontada por Bonifácio está na busca de compreensão da sociedade portuguesa a partir de uma série ampla de indicadores, sejam eles geográficos, "sócioecológicos" e culturais. A partir daí procurava Martins entender "o que nessa mesma sociedade a talhava ou predispunha

\footnotetext{
${ }^{20}$ BIACHI, Giorgio. Reação. In: Dicionário de Política. Obra citada, 1992, p. 1073-1074.

${ }^{21}$ LEVI, Lucio. Regime Político. In: Dicionário de Política. Obra citada, 1992, p. 1081.

22 BONIFÁCIO, Maria de Fátima. Historiografia do Estado Novo. In: Estudos de História Contemporânea de Portugal. Lisboa: Imprensa de Ciências Sociais, 2007, p. 95
} 
a se fazer moldar ao autoritarismo do Estado Novo"23. Ainda que, a meu ver, a natureza ensaística de Martins bem como a utilização de uma ampla gama de variáveis, o aproximem da tradição que tem em António Sérgio seu principal expoente, as conclusões chegadas pelo primeiro afastam-no do autor da Introdução Geográfico Sociológica da História de Portugal e da Breve Interpretação da História de Portugal. Enquanto que para Sérgio, Portugal era um país heterogêneo e dotado de múltiplas características, assim como os "demais países” da Ibéria ${ }^{24}$, Martins começa em seu ensaio por afirmar que "Portugal não é uma sociedade "plural". Para ele o grau de homogeneização portuguesa é imenso em comparação com os demais países da Europa, tanto do ponto de vista racial quanto, linguístico, religioso ou cultural ${ }^{25}$. Trata-se de uma homogeneidade iniciada com a formação precoce de seu Estado Nacional e que se mantém graças ao elevado grau de concentração de renda que se manteve no país ao longo de toda a sua história. Assim, enquanto que aristocracia fundiária, aristocracia financeira ou burguesia industrial constituem grupos distintos nas demais sociedades europeias, em Portugal os pontos de interseção e unidade entre estas classes são preponderantes. A homogeneidade de um país com imensa concentração de renda e poderes nas mãos de 1,2\% da "classe alta" em detrimento de uma grande maioria "classes subordinadas", cerca de $74 \%$, teria impedido a luta pela obtenção da cidadania, valor dominante nos países do Noroeste da Europa $^{26}$. Este conjunto triste de características teria conduzido a sociedade portuguesa à dominação. O fascismo em Portugal, para Martins, destoaria então das demais experiências fascistas, caracterizadas pela crise do sistema liberal em meio a alternativas diversas e mesmo heterogêneas. $\mathrm{O}$ autoritarismo português seria consequência da fragilidade de suas classes sociais e não de um certo equilíbrio tensionado e de difícil sustentação.

23 Idem.

${ }^{24}$ SÉRGIO, António. Introdução Geográfico-Sociológica à História de Portugal. $3^{a}$ edição. Lisboa: Clássicos Sá da Costa, 1976, p. 23-37.

25 MARTINS, Hermínio. Classe, status e poder em Portugal. In: Classe, status e poder e outros ensaios sobre o Portugal Contemporâneo. Lisboa: Imprensa de Ciências Sociais, 1998, p. 99.

26 Idem, p. 105-131. Ver também, do mesmo autor: O Estado Novo. In: Classe, status e poder e outros ensaios sobre o Portugal Contemporâneo Obra citada, p. 19-51. 
Conforme disse na abertura deste texto, o trabalho que provavelmente mais marcou os debates e as investigações seguintes a respeito do Estado Novo foi aquele produzido por Manuel de Lucena. O método escolhido por este investigador foi o da comparação com o regime italiano. Lucena entende o fascismo a partir de três prismas: a ideologia, o movimento e o Estado. Ao mesmo tempo considera possível classificar o regime fascista apenas a partir de seu aparato institucional, ou seja, a partir de seu funcionamento como um Estado relativamente estável. Partindo deste prisma e analisando os casos português e italiano, aponta para a "indubitável semelhança" entre um e outro. Reconhece ao mesmo tempo a ausência de um "movimento subversivo", daí a conhecida caracterização do Estado Novo como um fascismo sem movimento fascista ${ }^{27}$.

Aqui cabe, a meu ver, uma breve indagação a respeito da possibilidade de existência de um "fascismo sem movimento fascista". Walter Benjamin, já em 1936 afirmava que o fascismo deliberadamente substituiu o debate ponderado pela experiência sensorial, o que transformou a política em estética. E concluiu premonitoriamente que a grande experiência estética fascista seria a guerra. Benjamin lembra da afirmação de Marinetti acerca da beleza da Guerra da Etiópia: “(...) [a guerra] enriquece um campo florido com as orquídeas de fogo das metralhadoras" ${ }^{28}$. Assim, o movimento, como que um ensaio com vistas a um desejado futuro guerreiro, afigura-se determinante para a inauguração de uma estética/política que se mantém no regime e que busca sua consagração no enfrentamento: primeiro nas ruas, depois nas trincheiras.

Em interpretação semelhante à de Lucena, Manuel Vilaverde Cabral compreende o fascismo - e o Estado Novo - a partir de suas estruturas, ou seja, o regime, e não de suas circunstâncias, o movimento. Dando ênfase à forma do Estado e às suas estruturas de funcionamento, o regime português seria uma das variantes mais importantes e bem acabadas "da espécie negra do fascismo" 29 .

${ }^{27}$ LUCENA, Manuel de. A evolução do sistema corporativo português. Obra citada, p. 27.

${ }^{28}$ Citado por PAXTON, Robert. A anatomia do fascismo. Obra citada, p. 39-40.

29 CABRAL, Manuel Vilaverde. O fascismo português numa perspectiva comparada. In: AAVV. O fascismo em Portugal. Lisboa: A Regra do Jogo, 1982, p. 30. 
Também Vilaverde Cabral reconhece a ausência de um partido que tivesse protagonizado a ascensão do fascismo em Portugal. As razões da ausência de liderança de um partido fascista em Portugal decorreram da combinação de elementos de natureza ideológica com outros de caráter estrutural: por um lado a fragilidade e incapacidade da pequena burguesia de reagir frente ao Estado parlamentar, daí a necessidade da alternativa militar e cesarista; por outro, reconhece Vilaverde Cabral o peso ideológico da reação monárquica e católica. A alternativa autoritária portuguesa deve ser entendida no contexto do capitalismo dependente e da crise do estado liberal, mas de uma crise endógena, mais "portuguesa" que internacional ${ }^{30}$. Ao mesmo tempo considera que o fascismo foi uma experiência mais apropriada às ditaduras do sul da Europa, separando-o do nacional-socialismo, de cores notadamente totalitárias ${ }^{31}$.

O totalitarismo é, igualmente ao fascismo, um conceito que se modificou com o passar dos anos. Não é função deste paper tratar do tema do totalitarismo. Apenas, com a máxima brevidade, gostaria de apontar para alguns problemas decorrentes de sua instrumentalização como conceito. Desconsidera Cabral que o próprio Mussolini reivindicou para o fascismo italiano a condição de regime totalitário. A partir da segunda metade da década de 1940, entretanto, com a eclosão da Guerra Fria, o totalitarismo foi crescentemente entendido como expressão de uma ditadura absoluta e a-histórica. Desde então, nazismo e comunismo passaram a fazer parte da mesma arquitetura ${ }^{32}$. No caso da Alemanha, o pós-guerra ensejou dois tipos de memória a respeito do passado nazista. Uma, cara à República Federal Alemã, e condizente com as teorias do totalitarismo então em voga no conjuntura de guerra-fria, lembrava o passado nazista como um acontecimento no qual o povo alemão foi vítima, manipulado pela eficiente propaganda e, sobretudo por seu chefe, Adolf Hitler. A segunda, predominante na República Democrática da Alemanha, superestimava os movimentos de libertação e identificava-os acriticamente com o povo. Interpretações aparentemente diversas, que se encontravam na ausência do

\footnotetext{
30 Idem, p. 26.

${ }^{31}$ CABRAL, Manuel Vilaverde. Portuguese Fascism in Comparative Perspective. In: $12^{\circ}$ IPSA World Congress. Rio de Janeiro, Agosto de 1982.

32 TEIXEIRA DA SILVA, Francisco Carlos. Os fascismos. Obra citada, p. 119.
} 
povo como personagem construtor do nazismo ${ }^{33}$. A desconsideração de nuanças históricas e, sobretudo, da capacidade de agir cotidiano relativamente autônomo - tanto em favor como contra o regime em questão - afasta-me do conceito sob qualquer hipótese ou circunstância ${ }^{34}$. Ao mesmo tempo quero crer que a interpretação de Vilaverde Cabral gera mais problemas que propriamente soluções, na medida em que aproxima o Estado Novo do fascismo italiano e ao mesmo tempo afasta abruptamente este último do nazismo. É bom lembrar, por fim, que tanto os regimes alemão quanto o italiano desejavam o totalitarismo. Neste sentido esforçavam-se para que a esfera pública, entendida como a existência de alguma sociedade civil autônoma, sucumbisse à razão do Estado ${ }^{35}$. Esta não foi a realidade do Estado Novo português. Verdade que liberdades foram cerceadas; verdade que jornais foram censurados; verdade, enfim, que o sistema repressor do regime funcionou com todo o rigor. Mas dentro do próprio staff da ditadura houve sempre espaços para alguma ação autônoma. Não por acaso empresários criticaram abertamente as políticas sociais do governo quando estas lhes pareceram prejudiciais ${ }^{36}$. E, ainda, é bom lembrar que Marcello Caetano criticou abertamente as ações do regime contra a Universidade, afirmando a sua autonomia ${ }^{37}$.

33 TEIXEIRA DA SILVA, Francisco Carlos \& SCHUSTER, Karl. Figura esvaziada de Hitler. In: Revista de História. Endereço eletrônico: http://www.revistadehistoria.com.br/secao/artigos/ figura-esvaziada-de-hitler Acesso em 17 de junho de 2011.

34 Lançada recentemente, a obra organizada por Denise Rollemberg e Samantha Quadrat procura entender as razões do apoio popular dado a diversos regimes autoritários, tanto de direita como de esquerda. O trabalho, de fundamental importância, sugere possibilidades diversas de apoio. Sobretudo, apontam para o que Pierre Laborie chama de zona cinzenta, a grande maioria das pessoas que não pela adesão militante, mas pela aceitação, o que não impede a legitimidade. De qualquer forma os diversos trabalhos recusam-se a aceitar tanto a concepção "totalitária" que manipula corações e mentes, quanto também os movimentos de resistência, em geral supervalorizados quando falamos de ditaduras. Ver: ROLLEMBERG, Denise \& QUADRAT, Samantha (Organizadas). A construção social dos regimes autoritários. Legitimidade, consenso e consentimento no século XX: Europa. Rio de Janeiro: Civilização Brasileira, 2010.

35 BOBBIO, Norberto. O conceito de sociedade civil. $2^{\text {a }}$ edição. Rio de Janeiro: Graal, 1987.

36 MARTINHO, Francisco Carlos Palomanes. A bem da nação. O sindicalismo português entre a tradição e a modernidade (1933-1947). Rio de Janeiro: Civilização Brasileira, 2002, p. 146-150; PATRIARCA, Fátima. A questão social no salazarismo - 1930-1947. Lisboa: Imprensa Nacional/Casa da Moeda, 1995, p. 142-152.

37 CAETANO, Marcello. A Corporação Universitária. In: A Voz. Lisboa, 30 de março de 1949, p. 1. 


\section{As primeiras questões e o afastamento do fascismo.}

A partir da década de 1980, a unanimidade em torno do fascismo foi sendo aos poucos relativizada. Um dos primeiros autores a questionar a natureza fascista do Estado Novo foi Manuel Braga da Cruz. Para este historiador o Estado Novo deve ser compreendido fundamentalmente a partir de sua matriz social cristã. Estaria afastado do fascismo tanto pela ideologia como também pela organização política e pela ausência de condições históricas para a formação de um movimento fascista em Portugal. Neste sentido seria o regime de Salazar, porta-voz de um nacionalismo mais tipicamente tradicionalista e mais aproximado do conservadorismo que propriamente do fascismo ${ }^{38}$.

Braga da Cruz reconhece a presença de uma direita radical no pós-guerra com importância na derrubada do liberalismo e na implantação da ditadura militar (1926-1932). Entretanto, para ele o golpe de Estado e o protagonismo das Forças Armadas teriam secundarizado a oposição civil de perfil marcadamente ideológico e influenciada por Miguel Primo de Rivera e Benito Mussolini. A importância menor da oposição civil pode mesmo ser percebida no papel marginal que o Integralismo teve no Estado Novo, origem e motivo da oposição fascista ao regime de Salazar. O salazarismo seria, pois, uma ditadura de governo, e não de partido. A própria forma de dominação seria mais próxima de um exercício paternalista de poder, longe do modelo "inovador" de condução das massas à cena pública e às ruas ${ }^{39}$.

Outra questão cara a Manuel Braga da Cruz, tema de sua tese de doutoramento, diz respeito ao partido político. Neste sentido, aponta para diferenças fundamentais entre a União Nacional (UN) e os demais partidos fascistas. E reconhece Braga da Cruz que, assim como em Portugal, também na Itália o partido fascista se tornou dependente do Estado. Mas a UN, ao mesmo tempo em que não era o único vetor de acesso ao poder, tinha uma composição

38 BRAGA DA CRUZ, Manuel. As origens da democracia cristã em Portugal e o Salazarismo (I). In: Análise Social. Revista do Gabinete de Investigações Sociais da Universidade de Lisboa. V: XIV. $1978 / 2^{\circ}$, p. $265-278$; As origens da democracia cristã em Portugal e o Salazarismo (II). In: Análise Social. Revista do Gabinete de Investigação Social da Universidade de Lisboa. V: XIV, $\mathrm{N}^{\circ}$ 55, 1978/3, 525-607.

39 Idem, idem. 
social que demarcava dos partidos fascistas tradicionais. Constata Braga da Cruz a inexistência de qualquer componente pequeno-burguesa, popular ou operária na União Nacional. Ao contrário, sua composição era marcadamente de "notáveis locais": proprietários e comerciantes formavam a maioria de suas comissões locais na década de $1930^{40}$. Tratar-se-ia, pois, de um instrumento secundário na estrutura de poder do Estado Novo. Afirma o autor que esta subalternização fez da UN um órgão "sempre à margem do Estado e do Governo, fora do primeiro e nas mãos do segundo" ${ }^{41}$. Uma coisa então seria a sua dependência para com o Estado, comum aos fascismos em geral. Outra, bem diferente, seria sua minguada importância no aparelho estatal.

Ainda no interior do debate sobre a relação Estado Novo/fascismo, Fernando Rosas afirma a necessidade de reconhecimento de "cinco pontos" básicos para compreendê-lo como um fenômeno socialmente definido: em primeiro lugar, trata-se de um "autoritarismo moderno" que se desenvolve nas sociedades europeias desde o início do século xx mas que chega a seu ponto máximo com a crise do pós I Guerra e a Grande Depressão de 1929; a seguir, informa-nos Rosas que o advento do "autoritarismo moderno" está ligado à derrota e/ou incapacidade do movimento operário na conjuntura do pós-guerra; em terceiro lugar, assiste-se a uma forma "razoavelmente pacífica" de transição - ou rendição - do liberalismo para autoritarismo; é deste processo que surge um "fascismo em geral", com significativas semelhanças em quase toda a Europa; por fim, os regimes fascistas ou de tendência fascistizante são próprios dos países "relativamente dependentes e atrasados da Europa central e ocidental" ${ }^{2}$. Conforme veremos adiante, Rosas aponta para uma "apetência totalitária" do Estado Novo na década de 1930 e durante a Segunda Guerra Mundial. Mas opta por uma não definição peremptória da natureza do Estado Novo, deixando transparecer mais uma "vontade fascistizante" que propriamente sua efetivação.

${ }^{40}$ CRUZ, Manuel Braga da. O partido e o Estado no Salazarismo. Lisboa: Editorial Presença, 1988, p. 28-34.

${ }^{41}$ Idem, p. 255.

${ }^{42}$ ROSAS, Fernando. Cinco pontos em torno do estudo comparado do fascismo. In: Vértice. $\mathrm{N}^{\circ}$ 13. Lisboa, Abril de 1989, p. 21-29. 
Por fim, um outro historiador que tem trabalhado desde o final da década de 1980 com a relação Estado Novo/fascismo é António Costa Pinto. Para ele a temática das origens do Estado Novo costuma ser confundida com a questão, semelhante mas não idêntica, dos agentes que levaram à queda do liberalismo em Portugal. É que para Costa Pinto, os momentos de transição, primeiro para a queda da República liberal (1910-1926) e depois para o Estado Novo (1926-1933) devem ser vistos separadamente. Ao contrário de outros países europeus, em Portugal, setores que tiveram protagonismo no golpe militar de 1926 desempenharam, no Estado Novo, um papel apenas secundário ${ }^{43}$. Em outras palavras, ainda que derrotados no projeto autoritário que vingou em Portugal nos anos 1930, a direita radical e o fascismo desempenharam um papel importante no Portugal do pós-guerra e em toda a movimentação que conduziu à queda da I República ${ }^{44}$. Assim, o tempo e os personagens de um acontecimento, o derrube da República é um; os personagens de outro acontecimento, a implantação do Estado Novo é outro. Este é um tema importante que, a meu ver, demarca as análises de Costa Pinto e as de Luís Reis Torgal, para quem o Estado Novo constituiu-se em uma amálgama de correntes opositoras do liberalismo republicano. As teses de Torgal contrastam igualmente com as de Hermínio Martins mostradas acima. Enquanto o primeiro aponta para a homogeneidade, o segundo afirma a composição do Estado Novo a partir de matrizes diversas e até por vezes antagônicas. Matrizes que, mesmo guardadas eventuais divergências, unificam-se na oposição ao liberalismo e ao comunismo/socialismo ${ }^{45}$. São análises, pois, coerentes. Na medida em que Torgal, conforme veremos, identifica Estado Novo e fascismo, há para este historiador uma clara linha de continuidade entre a oposição à República e a montagem do regime. Esta foi a característica predominante nos fascismos clássicos. Costa Pinto, ao contrário, vê as elites opositoras da República mais próximas do fascismo que as elites instaladas nos aparelhos do Estado a seguir a ascensão de Salazar.

43 COSTA PINTO, António. O salazarismo e o fascismo europeu: problemas de interpretação nas ciências sociais. Lisboa: Editorial Estampa, 1992, p. 88.

${ }^{44}$ Idem, p. 90-91.

45 TORGAL, Luís Reis. Estado Novo e "Fascismo". Obra citada, p. 347-364. 
Reconhece Costa Pinto a formação de organizações paramilitares e o endurecimento do regime quando da Guerra Civil em Espanha. Estas organizações, como a Mocidade Portuguesa (MP) e a Legião Portuguesa (LP) nunca estiveram previstas em lei e eram vistas por Salazar com profunda hostilidade. $\mathrm{Na}$ melhor das hipóteses com desconfiança. Logo a seguir à vitória de Franco a coreografia de tipo fascista foi imediatamente secundarizada e a importância da MP e da LP tendeu a declinar ${ }^{46}$. Lembra ainda que tanto uma quanto outra organização acabaram enquadradas por um programa político de cristianização que atravessou todas as instituições do regime, sobretudo aquelas voltadas para a socialização, com especial importância dada ao aparelho escolar ${ }^{47}$.

Para além do fato de que as organizações tipicamente fascistas tiveram pouca "densidade" na história portuguesa, Costa Pinto defende a tese segundo a qual, do ponto de vista histórico, os regimes fascistas ficaram restritos apenas às ditaduras italiana e alemã ${ }^{48}$. Concorda, pois, com Saccomani, que faz uma clara distinção entre movimentos fascistas, presentes na maioria dos países europeus e latino americanos, e os regimes fascistas propriamente ditos, aqui apenas Itália e Alemanha ${ }^{49}$. Para Costa Pinto a ditadura férrea do presidente do Conselho impediu qualquer possibilidade de crescimento dos fascistas por dentro do Estado Novo. As raízes ideológicas do Estado Novo devem então, ser encontradas em uma cultura de direita tradicional e no peso cultural de um catolicismo conservador e antiliberal ${ }^{50}$.

Mas é na análise da construção institucional do salazarismo que Costa Pinto vê as principais diferenças entre o fascismo e o Estado Novo pois, ainda que inspirando-se nos regimes fascistas no poder, o regime português recusou voluntariamente, os elementos que lhe davam singularidade. Salazar teria conservado sempre os traços ideológicos de suas origens: o catolicismo tradicionalista em um quadro de laicização e modernização que, para o

46 COSTA PINTO, António. O salazarismo e o fascismo europeu... Obra citada, p. 127;

O Estado Novo português e a vaga autoritária dos anos 1930 e 1940. Obra citada, p. 33.

47 COSTA PINTO, António. O Estado Novo português e a vaga... Obra citada, p. 35-36.

48 COSTA PINTO, António. O salazarismo e o fascismo europeu. Obra citada, p. 113.

49 SACCOMANI, Edda. Fascismo. Obra citada, p. 466.

${ }^{50}$ COSTA PINTO, António. O salazarismo e o fascismo europeu... Obra citada, p. 121-122. 
ditador, eram simbolizados pela I República. Salazar teria sido, sempre, um ultra conservador, de modo que suas cosméticas proximidades com o fascismo eram menores que as divergências ${ }^{51}$.

Para Costa Pinto o corporativismo, ainda que sendo um dos elementos mais importantes da variante italiana do fascismo, recobriu um largo espectro ideológico da direita antidemocrática do início do século passado. Não era, pois, um monopólio fascista ${ }^{52}$. Neste sentido perde importância o fato ressaltado por Torgal de que Mihail Manoilescu, importante teórico do corporativismo, foi traduzido e lido à farta pelos portugueses durante o salazarismo ${ }^{53}$. Aliás foi também traduzido e lido no Brasil durante os anos do primeiro governo Vargas... Lembra então Costa Pinto que a concepção corporativa foi um elemento importante na legitimação de diversos regimes autoritários do entreguerras, como os da Áustria, Romênia, Espanha e mesmo a França de Vichy ${ }^{54}$.

Desta forma, o Estado Novo, mesmo durante a chamada "época do fascismo", era predominantemente conservador e teria se ancorado mais nos instrumentos de enquadramento tradicional que nas organizações de massa. Seria, pois, responsável pela promoção da apatia e do isolamento do pequeno universo urbano, sempre visto com desconfiança por parte de Salazar. Ao contrário do método de recrutamento de novas elites, como nos regimes fascistas, o salazarismo teria se pautado no apoio permanente de dois grandes agentes do "Portugal profundo": as elites locais e a Igreja Católica ${ }^{55}$ Enfim, tratava-se de um regime voluntariamente não totalitário e que restringia o direito à participação política quase que exclusivamente às suas elites ${ }^{56}$.

Quanto à União Nacional, as teses de António Costa Pinto aproximam-se em larga medida daquelas defendidas por Manuel Braga da Cruz. Para Costa Pinto, dada a natureza não fascista da União Nacional e a sua inspiração a partir do alto, qualquer comparação com os partidos fascistas serve apenas

\footnotetext{
${ }^{51}$ Idem, p. 123.

52 Idem, p. 126.

53 TORGAL, Luís Reis. Estado Novo e "Fascismo". Obra citada, p. 350.

54 COSTA PINTO, António. O salazarismo e o fascismo europeu... Obra citada, p. 126.

55 Idem, idem.

${ }^{56}$ Idem, p. 127.
} 
para acentuar as diferenças ${ }^{57}$. Não que o partido - ou "não partido", como dizia Salazar - não tivesse importância na institucionalização do regime. Ainda que não tivesse importância na formação de novas elites para o regime a UN reforçou a autoridade de Salazar e reduziu a pressão de grupos autônomos ${ }^{58}$.

\section{De volta ao fascismo...}

Iniciado o século XXI, os estudos sobre o Estado Novo deram uma interessante guinada, de modo que boa parte dos autores portugueses retornaram às teses do fascismo dominantes da década de 1970 e primeira parte da seguinte. Luís Reis Torgal, autor já antes citado, procura definir o Estado Novo mais a partir de seu conteúdo sistemático e historiográfico que propriamente de uma teorização. Aproxima-se pois, como ele mesmo informa, da perspectiva apontada por Angelo Tasca: "Para nós, definir o fascismo é antes de tudo, escrever sua história"59. E, "contando a história", lembra tanto que Salazar procurava formalmente afastar-se do fascismo italiano quanto o fato de que "praticamente nenhum regime se assumia como fascista". Lembra ainda à guiza de exemplo, o caso do ditador espanhol Miguel Primo de Rivera, que ora se afirmava fascista, ora criticava os fundamentos da ideologia ${ }^{60}$. Mais ainda, defende a tese de que o fascismo pode ser entendido a partir de uma perspectiva "abrangente”, razão pela qual é possível considerar fascista determinado regime ainda que este não se assuma como tal. Em outras palavras, existiria para Torgal, um "máximo" e um "mínimo" fascista. Um "mínimo" que, ainda assim, supõe complexidade e pluralidade ${ }^{61}$. É verdade, porém, que o "mínimo" fascista capaz de identificar o Estado Novo como tal reduz-se à sua circunstância institucional. Outro argumento que utiliza em seu favor é que alguns dos mais aguerridos salazaristas manifestaram a tendência para

\footnotetext{
57 Idem, p. 124.

58 Idem, idem.

59 Citado por TORGAL, Luís Reis. Estado Novo e "Fascismo". Obra citada, p. 302.

${ }^{60}$ Idem, p. 331.

61 Idem, p. 333-334.
} 
falar direta ou indiretamente de totalitarismo, tanto no que concerne ao partido único quanto na justificativa para a intervenção do Estado em todos os setores e na criação de uma ideologia unitária por intermédio da ação propagandística $^{62}$. É curioso, pois, que enquanto o discurso de Salazar a demarcar o Estado Novo do fascismo deve ser desconsiderado, os pronunciamentos de seus assessores servem na medida em que se aproximam da defesa do totalitarismo. Ou bem os dois discursos servem ou bem os dois devem ser desconsiderados.

O que seria, então, um conceito genérico de fascismo? Responde Torgal: 1. um sistema de terceira via entendida como uma nova opção política e sócioeconômica de tipo corporativo; 2 . um regime revolucionário que se assenta na ação de um partido único. Este regime, além da importância do partido está igualmente baseado na força carismática de um "Chefe"; 3. trata-se de um regime nacionalista, expansionista e imperialista, com suas decorrentes concepções de "homem novo", "nova Europa”, etc; 4. os fascismos seriam regimes característicos do pós-guerra, modernizados e voltados para o Progresso; 5. seriam, por fim, regimes influenciados ideológica e culturalmente por correntes variadas e mesmo contraditórias que abarcariam dentre outras, o antiintelectualismo de Bergson e Nietzsche, a cultura da violência de Sorel, o antissemitismo e até mesmo formas diversas de modernismo vanguardista ${ }^{63}$.

É a partir deste conjunto de características que Torgal vai se pronunciar a respeito da relação entre Estado Novo e fascismo. Para este historiador, o Estado Novo é, indubitavelmente, um regime de terceira via que se pretende alternativa tanto ao liberalismo como ao comunismo. Os argumentos de Salazar contra a democracia liberal seriam mesmo muito próximos aos utilizados por Mussolini já que ambos a consideravam ultrapassada. O corporativismo, argumento primeiro e último da "terceira via" estava presente, lembra Torgal, na própria Constituição portuguesa. ${ }^{64}$ Outro ponto de análise que aproximaria o Estado Novo do fascismo é no que diz respeito à base de apoio do regime português. Ainda que seja para ele indiscutível a

\footnotetext{
62 Idem, p. 354.

63 Idem, p. 337-341.

64 Idem, p. 347.
} 
importância de Salazar, o Estado Novo não se resumia ao Chefe. Como nos demais regimes fascistas, foi também ele uma convergência de políticas de várias origens. Torgal reconhece a importância da matriz católica do regime. Mas a componente cultural do Estado Novo, a seu ver, deve ser entendida a partir da unidade do catolicismo com o fascismo. Cita, em favor de seus argumentos, o caso do Integralismo Lusitano e da presença de diversos de seus militantes de primeira hora, como Marcello Caetano, entre os adeptos do Estado Novo ${ }^{65}$. Não é o que pensa, como já antes apontei, António Costa Pinto, para quem o projeto cultural do regime salazarista procurou, como em outros regimes similares, uma busca sistemática da tradição ${ }^{66}$. Também em sua tese de doutoramento Costa Pinto aponta para a ruptura, como também fez Manuel Braga da Cruz, dos fascistas em relação ao Estado Novo. Aqueles que aderiram ao regime o fizeram abdicando de seus valores pretéritos ${ }^{67}$.

As conclusões de Torgal são, como o próprio diz, provisórias. E elas apontam para a afirmação de que o Estado Novo era um tipo de fascismo. Um "fascismo à portuguesa”. E este "à portuguesa” não chega a constituir um problema. Afinal de contas, como o próprio autor lembra, todos os nacionalismos se preocupam em afirmar sua "originalidade" 68 . Não seria pois, o caso português uma exceção. Enfim, trata-se de um fascismo adaptado às circunstâncias de um povo essencialmente rural, com fraca densidade urbana e dotado de uma mentalidade católica e tradicionalista. E, retornando às definições conceituais do início de seu texto, afirma que considera o Estado Novo fascista por uma opção. Não uma opção fundamentada, como fez Manuel de Lucena, em comparação com o fascismo italiano ou com outras experiências. Parte sua escolha, como dissemos, de uma reflexão que tem como referência uma ideia "genérica" de fascismo. Ideia essa que, apesar de

65 Idem, p. 349-350.

66 COSTA PINTO, António. O Estado Novo português e a vaga autoritária nos anos 1930. In: COSTA PINTO, António \& MARTINHO, Francisco Carlos Palomanes (Organizadores). O corporativismo em português. Estado, politica e sociedade no salazarismo e no varguismo. Rio de Janeiro: Civilização Brasileira, 2007, p. 12.

67 COSTA PINTO, António. Os camisas azuis: Ideologia, elites e movimentos fascistas em Portugal 1914-1945. Lisboa: Editorial Estampa, 1994, p. 76-92.

68 TORGAL, Luís Reis. Estado Novo e "Fascismo". Obra citada, p. 364-367. 
sua generalidade, pode - e deve - ser utilizada como categoria historiográfica definida ${ }^{69}$.

Um último trabalho que gostaria de analisar é o de Manuel Loff. Trata-se de uma tese de doutoramento defendida em 2004 junto ao Instituto de Estudos Europeus da Universidade de Florença e publicada em livro quatro anos depois $^{70}$. O estudo de Loff procura fazer uma densa e minuciosa comparação a respeito do franquismo e do salazarismo. Grosso modo, para Loff, os discursos dos ditadores Francisco Franco e Oliveira Salazar evidenciam clara simpatia pelos fascismos alemão e italiano, bem como o desejo de constituição de uma Nova Ordem, "expressão intrínseca ... em todos os regimes autoritários, fascistas ou fascistizados do período de 1936-45"71. Para o autor, ainda que reconhecendo a existência de autoritarismos não fascistas, Portugal e Espanha seriam exemplos, pelo menos na conjuntura 1936-45, de regimes que se fascistizaram. A política de neutralidade portuguesa não escondia o incômodo que Salazar sentia com relação à hegemonia britânica nem tampouco as maiores simpatias do próprio com relação a uma eventual vitória do Eixo.

No que diz respeito à rejeição à Inglaterra, lembra Loff de uma série de discursos de Salazar para quem, por exemplo, o ultimatum inglês de 1890 e as conversações anglo-alemãs a respeito de uma eventual partilha das colônias portuguesas "ficaram a envenenar por dezenas e dezenas de anos a amizade luso-britânica"72. A proximidade para com os Aliados, consubstanciada na concessão das bases militares nos Açores em 1944, deve ser vista, para este autor, como resultado de um pragmatismo que tinha por objetivo a continuidade do regime em uma conjuntura que já anunciava a derrota nazifascista ${ }^{73}$.

Creio que a análise dos discursos, ainda que importante instrumental para o historiador, deva ser tratada com mais cuidado. Já me referi a este problema em outra parte do texto e aqui retomo. Os discursos são fontes que devem

69 Idem, p. 364-365.

70 LOFF, Manuel. O Nosso Século é Fascista! O Mundo visto por Salazar e Franco (19361945). Porto: Campo das Letras, 2008.

71 Idem, p. 901.

72 Citado por LOFF, Manuel. Idem, p. 924.

73 Idem, p. 923. 
assim ser entendidas. Nem são a palavra final, expressão da verdade acabada, nem a mera enganação ardilosa de quem o pronuncia. No mínimo, outros discursos que apontam para o desgaste das relações luso-italianas ou luso-alemãs também deveriam ter sido citados por Loff. Lembro, por exemplo, de um texto de Marcello Caetano, publicado na imprensa onde fez duras críticas a Benito Mussolini e seu objetivo de partilhar a responsabilidade sobre as colônias portuguesas. Naquele texto Caetano afirmava a soberania portuguesa ao mesmo tempo em que afastava Portugal da Europa e de seus conflitos ideológicos, à direita e à esquerda ${ }^{74}$. Se alguma mágoa havia para com a Inglaterra, havia também - mesmo que mais recente - para com a Itália mussoliniana. O otimismo no início da década de 1940 com relação a uma eventual vitória do Eixo não tornava, necessariamente, o regime português (nem o espanhol) fascista. Provavelmente, e esta é uma questão a ser analisada em pesquisas futuras, ele apenas apontava para uma possibilidade maior de permanência do autoritarismo corporativo do Estado Novo. Como se pode ver, os trabalhos de Loff e Torgal se aproximam na definição do Estado Novo como fascista. Mas enquanto o primeiro utiliza-se dos discursos dos como fonte fundamental, o segundo rejeita-os devido as evidentes as oscilações de quem os pronuncia. Caminhos diversos que se encontram ao final das contas...

\section{A dinâmica tradição/modernidade}

Nos dois itens a seguir trabalharei com temas que me parecem capitais para o que pretendo com o presente texto. Os autores que até então foram apresentados a partir de uma ordem mais ou menos cronológica serão abordados a partir do tratamento que dão (ou deram) aos temas escolhidos.

Gostaria de começar esta parte, entretanto, com um discurso de Salazar, a respeito das diferenças entre o campo e a cidade. Sobre este tema assim se pronunciava, já na década de 1960 o ditador: "Eu sou um rural ...

${ }^{74}$ Cf. MARTINHO, Francisco Carlos Palomanes. Marcello Caetano et l'espace de la modernité dans l'État Nouveau portugais. In: REIS FILHO, Daniel Aarão \& ROLLAND, Denis (Dir.). Modernités Alternatives: l'Historien face aux discours et représentations de la modernité. Paris: L'Harmattan, 2009, p. 43. 
Independentemente do que se possa chamar a poesia campestre, que atrai os sorrisos um tanto desdenhosos da economia industrial, por mim, e se tivesse de haver competição, continuaria a preferir a agricultura à indústria". ${ }^{75}$

O discurso do então Presidente do Conselho evidencia o incômodo sentido em relação às políticas de industrialização e modernização do Estado Novo. Eram elas, na melhor das hipóteses, um mal necessário. Ainda assim, através de uma política que ficou conhecida como de condicionamento industrial o país assistiu a uma lenta porém constante industrialização ${ }^{76}$.

Afirma, entretanto, António Costa Pinto que a relação entre o regime e a política econômica é controversa pois, para muitos autores, o fascismo nunca teve uma política econômica coerente e claramente definida ${ }^{77}$. No caso português, ainda de acordo com Costa Pinto, é difícil a análise do peso e das tensões daí decorrentes das elites rurais e industriais na condução da política econômica do regime. O que é pacífico entre os autores, é comum não só ao fascismo mas também ao conjunto dos demais regimes autoritários e corporativos europeus: repressão ao movimento sindical e criação de organizações corporativas controladas a partir de cima e a adoção de um modelo intervencionista e estatal no plano econômico, com relativo peso do setor burocrático ${ }^{78}$.

Para Fernando Rosas, o Estado Novo deve ser entendido como consequência da fragmentação e crise da burguesia, incapaz de arbitrar interesses contraditórios, interpretá-los como um todo e proceder à composição e ao equilíbrio. Aproxima-se, assim, das teses do bonapartismo: a elevação do Chefe decorre de um equilíbrio "por baixo", frágil, das classes sociais dominantes ${ }^{79}$.

75 SALAZAR, O. Erros e fracassos da era política. Discursos e notas políticas. Vol. VI: 19591966. Coimbra: Coimbra Editora, 1967, p. 195

76 MARTINHO, Francisco Carlos Palomanes. Entre o fomento e o condicionamento: a economia portuguesa em tempos de crise (1928-1945). in: LIMONCIC, Flávio \& MARTINHO, Francisco Carlos Palomanes (Organizadores). A Grande Depressão: Política e Economia na Década de 1930 - Europa, Américas, África e Ásia. Rio de Janeiro: Civilização Brasileira, 2009, p. 305-330.

77 COSTA PINTO, António. O salazarismo e o fascismo europeu... Obra citada, p. 97.

78 Idem, p. 98.

79 Sobre o Bonapartismo, ver: MARX, Karl. O 18 Brumário de Luís Bonaparte. In: FERNANDES, Florestan (Organizador). MARX/ENGELS - História. São Paulo: Ática, s/d, p. 280-292. 
Segundo Rosas, a função de árbitro atribuída ao Estado resultou em práticas econômicas contraditórias, titubeantes e presas à pura e simples racionalidade de garantir o equilíbrio do sistema ${ }^{80}$. Rosas, cuidadoso com a longa temporalidade do Estado Novo, aponta para o que chama de "apetência totalitária” nas décadas de 1930 e 1940, responsável pelo esforço de construção do "homem novo" salazarista. Este esforço do regime pode ser verificado, por exemplo, da adoção de uma política educacional sob a liderança do germanófilo Gustavo Cordeiro Ramos que, quando da reforma educacional de 1936 teria afirmado: "nos Estados renovados há uma concepção unitária de homem, um princípio de totalidade que se traduz na política e economia, na ciência, cultura e educação" ${ }^{81}$. Também pode ser visto no esforço de propaganda capitaneado por António Ferro à frente do SPN (Secretariado de Propaganda Nacional) organismo que, à revelia das vontades iniciais de Salazar, seria o vetor ideológico do regime no sentido de educação dos espíritos e da adequação destes à "nova Renascença"82. Esta "apetência totalitária", dadas as pressões internacionais no pós-guerra e o esforço de continuidade do regime, teria se esvanecido.

Reconhece Rosas, entretanto, que tal esforço totalizante, mesmo nas décadas de 1930 e 1940, esbarrava em um quadro heterogêneo de forças que apoiavam e davam sustentação ao Estado Novo. Quadro este que em larga medida limitava o a ação do radicalismo fascista. A começar pela formação católica do próprio Salazar e do peso da Igreja junto ao regime. O otimismo mobilizador dos movimentos fascistas foi sempre visto com desconfiança pelo ditador. Crítico da adulação às massas Salazar via no português um homem satisfeito com sua honrada modéstia ${ }^{83}$. Ou, como disse certa vez a Henri Massis, seu desejo era que o Estado Novo fosse capaz de fazer o homem português

80 ROSAS, Fernando. O Estado Novo nos Anos Trinta. $2^{\text {a }}$ Ed. (1928/1938). Lisboa: Estampa, 1986, p. 121.

${ }^{81}$ ROSAS, Fernando. O salazarismo e o homem novo: ensaio sobre o Estado Novo e a questão do totalitarismo. In: Análise Social. Revista do Instituto de Ciências Sociais da Universidade de Lisboa. (157), Vol. XXXV, 2001, p. 1040-1041.

82 Idem, p. 1043.

83 Idem, p. 1037 
"viver habitualmente" 84 . Nem tinha como ser diferente, para o chefe do regime, ao contrário de seus congêneres alemão, italiano e talvez mesmo espanhol, o povo português não tinha o tônus mítico do guerreiro ou do herói. Era mesmo, de certa forma, ingênuo, volátil, inconsequente, impressionável, algo infantil e irresponsável, portador talvez, de uma "bondade doentia"85. Precisava, pois de um chefe. E, sobretudo, não deveria sair à rua como protagonista. Não por acaso António Ferro, em seu livro de entrevista com Salazar conclamava o povo português a acalmar-se: "E agora que já o ouvimos, vamos cada qual para a nossa vida... Não façamos barulho... Deixemo-lo trabalhar...."86. É para mim evidente que o ideal de ruptura fascista é inconciliável com o pessimismo católico de Salazar e sua concepção conservadora e quase que tradicionalista de organização e gestão do Estado, opositor ferrenho da ideia de mobilização popular ${ }^{87}$.

As consequências do "viver habitualmente" do salazarismo são evidentes do ponto de vista institucional. Principalmente para a constituição de uma ditadura dotada de regulação e, mesmo que com nuanças, de um aparato jurídico ao qual ela deveria obedecer. A dominação política exercida pelo Estado Novo foi, assim, aquilo que Weber chamava de dominação tradicional, ou seja, aquela que está intrinsecamente ligada ao passado. E lembra o sociólogo alemão: "a [dominação] carismática subverte o passado ... e é nesse sentido especificamente revolucionária" ${ }^{88}$. A necessidade de ruptura presente na dominação carismática implica em uma relação efetivamente emotiva entre dominante e dominado: uma relação direta, sem burocracia ou hierarquia administrativa ${ }^{89}$. Ora, o Estado Novo teve, ou buscou ter, uma burocracia que, também ela, "vivia habitualmente". Além disso, a relação dominante dominado era bem mais uma espécie de repeito (ou medo) contido que propriamente

${ }^{84}$ MEDINA, João. Salazar em França. Lisboa: Ática, 1977, p. 50.

85 ROSAS, Fernando. O salazarismo e o homem novo... Obra citada, p. 1038.

86 FERRO, António. Entrevistas a Salazar. Lisboa: Parceria A. M. Pereira, 2007, 112.

87 MARCHI, Ricardo. Império, Nação, Revolução. As direitas radicais no fim do Estado Novo [1959-1974]. Lisboa: Editorial Texto, 2009, p. 308.

88 WEBER, Max. Economia y sociedad. México: Fondo de Cultura Económica, 1992, p. 195. ${ }^{89}$ Idem, p. 194-195. 
de qualquer forma de adesão emotiva. O próprio Salazar, avesso a manifestações de rua ou paramilitares típicas do fascismo contribuía para este olhar conservador a seu respeito. Marcello Caetano, quando Comissário Nacional da Mocidade Portuguesa não cansou de reclamar da ausência do Chefe dos acampamentos e manifestações da organização ${ }^{90}$. Era um ditador do gabinete, bem mais que das ruas ou das massas. É neste sentido que não concordo com a tese segundo a qual Salazar, a seu modo, tinha certo carisma. Ora, claro está que o "fascismo de cátedra", como nos diz Miguel de Unamuno"1 é, necessariamente, oposto a qualquer projeto ou modelo carismático ${ }^{92}$. A não ser que se esteja a utilizar o conceito de forma indevida, genérica.

Luís Reis Torgal considera que o Estado Novo resulta de uma consciência de crise política, moral, financeira e econômica própria do período. Por isso, ergue-se como um regime cujo Chefe, Oliveira Salazar, é apresentado como "salvador das finanças" e da credibilidade externa de Portugal. "Assim é também um regime modernizador, servido de uma campanha notável"93. O alegado "ruralismo" de Salazar não desmente, na perspectiva de Torgal, este sentido modernizante. A particular identidade do ditador com o "povo rural" não exclui a importância que dava à cidade. A par do "ruralismo" e da "casa portuguesa”, não deixa o regime de manifestar uma estética arquitetônica, por exemplo, ao estilo greco-romano, que caracterizou um "estilo de época" e que se integrou na lógica dos países autoritários e totalitários, fascistas e comunistas $^{94}$. Por fim, considera Torgal que a historiografia econômica e social do Estado Novo nunca encontrou elementos para considerar o salazarismo como fora da esfera do "fascismo genérico"95.

O "estilo de época" modernista, entretanto, não deve ser interpretado, a meu ver, como expressão exclusiva de uma estética fascista. Não foi nem

${ }^{90}$ ANTUNES, José Freire. Salazar e Caetano: cartas secretas (1932-1968). Lisboa: Difusão Cultura, 1994, p. 112-114; 123.

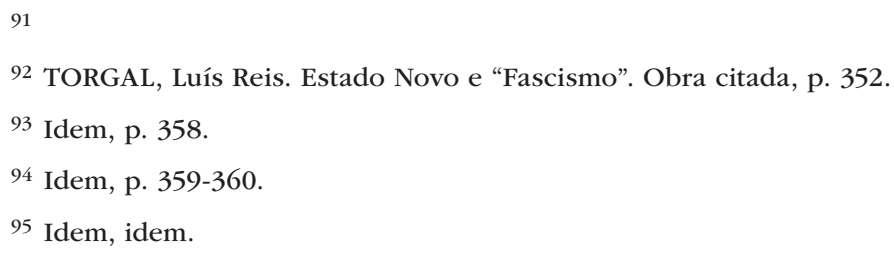


peculiaridade dos regimes autoritários em geral e muito menos dos "totalitarismos”. A própria Ringstrasse vienense, marco fundador desta moderna arquitetura que se vai consagrar no século $\mathrm{xx}$, nasce exatamente quando do advento do liberalismo em Viena ${ }^{96}$. Além disso, na década de 1930, modelos arquitetônicos similares podiam ser vistos tanto em Berlim e Roma quanto em Nova Iorque ${ }^{97}$.

Para Torgal, por fim, o entendimento da relação tradição/modernidade no Estado Novo parte de um tipo de análise que vai de encontro às teses de Manuel Braga da Cruz e de Fernando Rosas. Enquanto que ambos, apesar das matrizes diferenciadas, concordam que a longevidade do Estado Novo aponta para rupturas, Torgal considera que ainda que o regime não seja idêntico em toda a sua história, as diferenças são mais de forma que de conteúdo: “... não devemos estabelecer qualquer distinção essencial entre os períodos do regime ao longo de cerca de quarenta anos"98.

\section{A descontinuidade dos fascismos clássicos e a continuidade do Estado Novo português}

Manuel Vilaverde Cabral, em seus trabalhos acima citados, aponta para a existência de um modelo de estagnação programada como consequência do compromisso histórico do salazarismo com o segmento agrário. Esta seria também uma das chaves para se entender a longevidade do regime: "quanto mais lento e controlado for o crescimento económico e social, tanto mais chances há que os efeitos inevitáveis do crescimento possam ser absorvidos sem terem posto em causa o modelo"99.

96 SHORSKE, Carl E. Da cena pública ao espaço provado: a arquitetura como crítica cultural. Pensando com a história: indagações na passagem para o modernismo. São Paulo: Companhia das Letras, 2000, p. 179-194.

97 Idem, idem.

98 TORGAL, Luís Reis. Estado Novo e "Fascismo". Obra citada, p. 344.

99 CABRAL, Manuel Vilaverde. Sobre o Fascismo e seu advento em Portugal: ensaio de interpretação a pretexto de alguns livros recentes. In: Análise Social. Lisboa: Revista do Gabinete de Investigações Sociais da Universidade de Lisboa. V. XII, N 48, 1976, p. 885. 
Também Manuel Loff analisa brevemente as razões da continuidade do regime salazarista no pós-45. Para ele a manutenção do Estado Novo não decorria de uma eventual característica mais amena em relação a seus congêneres italiano e alemão. Diz Loff que a estrutura interna do salazarismo em quase nada diferia das estruturas da França de Vichy ou da Hungria de Horthy. Se houve diferença, afirma, foi por que os dois regimes acima citados foram mais plurais em seu interior que o Portugal de Salazar (ou a Espanha de Franco) ${ }^{100}$. Apenas as condicionantes internacionais permitiram a permanência das ditaduras ibéricas em detrimento das demais. Esquece Loff, a meu ver, que as condicionantes internacionais estavam dadas antes: Portugal e Espanha, mais o primeiro que o segundo país, não participaram da guerra. E pelo menos no caso português, não houve participação no conflito pela simples razão de que faltava ao Estado Novo, desde o seu nascedouro, um ethos da violência e do expansionismo militar caro aos regimes fascistas.

É Fernando Rosas, entretanto, o historiador português que, em breve artigo, mais sistematicamente, procura analisar as razões da durabilidade do Estado Novo e do salazarismo. Aponta ele para três tipos de fatores que devem ser entendidos como hipóteses explicativas para a permanência do Estado Novo. Em primeiro lugar, o que chama de fatores estruturais, em grande parte ligados às condicionantes externas: a) a situação periférica, dependente e pouco industrializada do país, com um imenso peso da economia rural, tradicionalista e fortemente resistente à mudança; b) além de semi-periférico e dependente, Portugal era também um país colonial e este "Império" servia como escoadouro de mercadorias e de capitais, além de ser fonte barata de matéria-prima e bens alimentícios capazes de enfrentar conjunturas de crise e, como consequência, bloquear eventuais rupturas; c) o papel geoestratégico de Portugal e de suas ilhas nas principais rotas marítimas do Atlântico Norte, o que colocava o país em posição privilegiada de interlocutor com as grandes potências marítimas. Desta vantagem teria se valido Salazar para revalorizar sua posição no contexto da Guerra Civil Espanhola; manter-se afastado da II Guerra Mundial obtendo grandes vantagens econômicas com o estatuto de neutralidade; obter apoio das democracias ocidentais no imediato

${ }^{100}$ LOFF, Manuel. O nosso século é fascista!... Obra citada, p. 904. 
pós-guerra, mesmo em uma conjuntura de relativa fragilidade; conquistar um posto na OTAN e, por seu intermédio, legitimação e respeitabilidade nos anos 1950; e, por fim, assegurar algum apoio militar e logístico durante a Guerra Colonial ${ }^{101}$.

Não obstante a importância dessas "condicionantes externas", Rosas reconhece serem elas insuficientes para a explicação do porquê da longevidade do regime. Falta-lhes a combinação com elementos de ordem interna e duradoura. Estes, que em parte combinam com os primeiros fatores seriam: a) o peso econômico, social e político do mundo rural tradicional, resistente a qualquer reforma fundiária e agrícola modernizante e, por isso, bloqueador do arranque industrial ou, pelo menos, de seu maior impacto. Uma imensa massa rural analfabeta e submissa que foi determinante para a permanência e conservação da "ordem estabelecida"; b) a classe dominante portuguesa seria caracterizada por uma grande debilidade econômica global, dependência externa, divisão interna e fragilidade que a impedia de hegemonizar processos de conservação e de mudança. Seria este um elemento central na capacidade de durar do Estado Novo; c) por fim, a relativa debilidade do proletariado industrial. O lento processo de crescimento das grandes indústrias, o peso do artesanato industrial e a política oficial de contenção da concentração (pelo menos até o fim da Segunda Guerra Mundial) moldou uma classe operária relativamente pouco numerosa ( $21 \%$ da força de trabalho ativa em 1940) e com apenas uma região tipicamente proletária: o espaço compreendido pelas zonas operárias de Lisboa e as "cinturas industriais ao norte e ao sul do rio Tejo ${ }^{102}$.

Por fim, ainda que a meu ver com menor peso conferido pelo autor, Rosas aponta para as condicionantes políticas: a) a arte de construir e reconstruir equilíbrios de acordo com as circunstâncias internas. Para Salazar, sobreviver politicamente era o objetivo central. Assim, na medida em que o regime se via obrigado a alguma evolução ela era vista como cedência, titubeante e sempre tendente ao bloqueio; b) uma burguesia parasitária e fortemente dependente do Estado e temerosa das mudanças ameaçadoras de sua hegemonia econômica; c) a incapacidade da oposição em se afirmar como alternativa política. Após

101 ROSAS, Fernando. Salazar e o salazarismo... Obra citada, p. 17-18.

102 Idem, p. 19-23. 
uma fase inicial (anos 30) de "Reviralhismo", com tentativas de levantes revolucionários e mesmo de um atentado contra a vida de Salazar, a oposição teria, no pós-guerra, oscilado entre conspirações palacianas, muitas vezes com o apoio e mesmo o protagonismo de "fascistas arrependidos", e o legalismo através de tentativas de impor ao regime seu estatuto legal; d) por fim, o aparato repressivo através da PVDE (Polícia de Vigilância e Defesa do Estado) que em 1945 mudou seu nome para PIDE (Polícia Internacional de Defesa do Estado) ${ }^{103}$.

$\mathrm{Na}$ medida em que os argumentos de Rosas obedecem a uma perspectiva estrutural (condicionantes internacionais, nacionais, estrutura de classe...), creio que faz-se hoje necessária uma análise a partir dos pressupostos da História Política para entender em que medida as escolhas conjunturais do regime também permitiram a sua continuidade. Por mais que possam ser vistas como meramente "cosméticas", alterações de forma e conteúdo no pós-45 não deixam de ter importância. Para Boaventura de Souza Santos, a partir dos anos sessenta o colonialismo havia substituído o corporativismo com núcleo central do regime ${ }^{104}$. De fato a retirada do Estado das negociações salariais foi um golpe de morte no otimismo corporativo dos anos trinta. Mas considero que a crise portuguesa era ainda mais profunda. Para sua coesão interna, até meados da década de 1940, o regime se mantinha ancorado em quatro grandes referências ideológicas: colonialismo, nacionalismo, corporativismo e autoritarismo. O primeiro vinculava-se à nostalgia de um tempo em que Portugal havia sido pioneiro nas grandes navegações e dono de um vasto território no Ultramar, um tempo em que "o sol não se punha" em terras portuguesas. O nacionalismo era o suporte de mobilização popular em uma conjuntura, a dos anos 30, marcada por diversos projetos que se pretendiam alternativos ao liberalismo e ao comunismo. O corporativismo possibilitava uma organização institucional que, se não conseguiu eliminar os conflitos sociais, ao menos impôs limites a radicalizações maiores dando argumentos ao Estado para a regulação das relações entre capital e trabalho. Por fim, o autoritarismo representava o descrédito frente às democracias representativas.

103 Idem, p. 23-31.

104 SANTOS, Boaventura de Souza. A crise e a reconstrução do Estado em Portugal. Pensamiento Iberoamericano. Madrid, n 5, Enero-Julio 1984, p. 507. 
Terminada a guerra os pilares acima citados, foram perdendo força e razão de existência. E começaram a ruir. Deste modo, ao chegarem os anos 60, apenas o colonialismo mantinha-se inalterado. $\mathrm{O}$ nacionalismo definhou na medida em que passou a servir como suporte para as lutas de libertação no Terceiro Mundo. E era utilizado à farta como instrumento contra a ditadura e não mais em seu favor. $O$ corporativismo perdia razão de existência devido ao papel destacado que os sindicatos passaram a ter, na Europa e nos Estados Unidos, como elementos de negociação e participação nas instâncias de poder. Manter a força dos sindicatos e os trabalhadores mobilizados com relativa autonomia era tudo que o regime não queria. Quanto ao autoritarismo, seu tempo da afirmação positiva tinha passado e era melhor esquecer o enaltecimento da ditadura exatamente para mantê-la intacta. No mundo da guerra fria, para o chamado bloco ocidental, autoritários deveriam ser apenas os regimes comunistas. Restava apenas o colonialismo. Curiosamente, a mais antiga das heranças acima apontadas. Exatamente aquela que se originou não no século $\mathrm{XX}$, mas no XV, com a fantástica aventura das grandes navegações, em que os portugueses haviam sido pioneiros ${ }^{105}$. Foi neste quadro de perda de referências que, em parte, o regime mudou. As reformas de 1947 têm, a meu ver, importância significativa. Apenas à guiza de exemplo, o Decreto-lei $n^{\circ}$ 36.173, de 6 de março de 1947, retira o Estado das negociações laborais. Estas, a partir de então, passam a obedecer a uma lógica de mercado que fragiliza, em muito, a capacidade de reivindicação dos sindicatos. Ainda que fosse real e dura a tutela do Estado sobre o aparelho sindical, as negociações tripartite (Estado, trabalhadores e empresários) tendia a aproximar os dois primeiros personagens em detrimento do último. Um sindicalismo, pois, à moda do do corporativismo estatal clássico, chegava ao fim ${ }^{106}$.

105 MARTINHO, Francisco Carlos Palomanes. A ordenação do trabalho e a nostalgia do Império: o Estado Novo português e as razões do consentimento (1933-1974). in: ROLLEMBERG, Denise \& QUADRAT, Samantha (Organizadas). A construção social dos regimes autoritários. Legitimidade, consenso e consentimento no século XX: Europa. Rio de Janeiro: Civilização Brasileira, 2010, p. 294-295.

106 MARTINHO, Francisco Carlos Palomanes. A Bem da Nação: ... Obra citada, p. 314; PATRIARCA, Fátima. A questão social no Salazarismo, 1930-1947. Obra citada; O triângulo corporativo. Acta e encenação de um despacho salarial (1946-47). In: Análise Social. Revista 


\section{Conclusão}

Os textos aqui discutido foram elaborados em épocas diversas e com metodologias e perspectivas de análise próprias. Como disse, Hermínio Martins faz um ensaio. Os textos de Manuel de Lucena, Manuel Braga da Cruz, Fernando Rosas e Manuel Loff são, em sua maioria, resultados de pesquisas com vistas à produção de teses ou textos originais. Os de António Costa Pinto, uma tese e um debate historiográfico. Também o texto de Luís Reis Torgal é um balanço historiográfico. Enfim: são textos que, ainda que se encontrem e sejam passíveis de análise conjunta, obedecem a perspectivas próprias. Perspectivas essas que talvez torne um tanto quanto abusada a análise comparativa. Foi um risco que assumo, mas creio ter escolhido autores e trabalhos bem representativos tanto da época quanto do enfoque tratado.

Minhas conclusões aqui apresentadas são iniciais, breves e passíveis de eventuais alterações. Servem mais para tentar dar continuidade ao debate que propriamente para encerrá-lo. Não teria essa pretensão... Afinal de contas, “nossas certezas são sempre provisórias". A primeira questão que gostaria de abordar é que lamento o abandono da tradição ensaística tão cara a António Sérgio e presente nos trabalhos iniciais de Hermínio Martins. Este modelo pode dar pistas importantes para o entendimento da "longa respiração das mentalidades". Eduardo Lourenço fez isso, com êxito, ao analisar os quinhentos anos de partida das caravelas e seu retorno sem colônias e sem Império ${ }^{107}$. Assim, quero crer que as referências ao passado utilizadas pelo salazarismo, evocadoras do sebastianismo e do miguelismo não devem ser desprezadas no entendimento da formatação do regime ${ }^{108}$.

Continuo a desconfiar das teses que reduzem o fascismo à sua experiência institucional. A vocação para a guerra, o enfrentamento, é característica basilar do fenômeno e responsável por sua formatação como regime. Talvez por

do Gabinete de Investigações Sociais da Universidade de Lisboa. V: XXIII, N 99, 1987/5² p. 905-944.

107 LOURENÇO, Eduardo. A nau de Ícaro. São Paulo: Companhia das Letras, 2001.

108 LEAL, Ernesto Castro. Nação e nacionalismos: a Cruzada Nacional D. Nuno Álvares Pereira e as origens do Estado Novo (1918-1938). Lisboa: Cosmos, 1999; António Ferro: Espaço Político e Imaginário Social (1918-1932). Lisboa: Cosmos, 1994. 
isso, no caso do Estado Novo, as instituições de tipo fascista, como a Legião Portuguesa e a Mocidade Portuguesa não tenham - salvo na breve conjuntura da Guerra Civil Espanhola - funcionado de acordo com “a prática dos valores que animam essas instituições", submetidas que estavam aos ditames do Estado e, sobretudo, da Igreja Católica. Ainda que me afaste da caracterização do fascismo para o Estado Novo considero também arriscadas as análises que restringem o fascismo aos casos italiano e alemão. Estudos a respeito de países envolvidos na Guerra, como a Hungria, a Romênia ou a Bulgária podem contribuir para novas linhas de investigação.

A União Nacional foi única, é fato. Mas não foi nem um partido e muito menos de massa. Tratava-se mais de uma organização destinada à representação parlamentar de grupos dominantes tradicionais, Os "notáveis locais", no dizer de Braga da Cruz. A UN, ao contrário dos partidos propriamente fascistas, nem trouxe novas elites à cena pública, nem levou multidões às ruas. Foi, antes, um dos vetores para a ocupação de cargos no aparato estatal do regime. O mesmo se pode falar de outras instituições, como a Universidade ou a Câmara Corporativa. Também a meu ver não se caracterizou como um partido que tivesse a tarefa de cultuar o Chefe. A relação com Salazar, parece-me, era mais próxima do respeito que da adoração.

O Estado Novo também não foi um regime revolucionário, malgrada a sua evocação à "Revolução Nacional de 1926". Na prática funcionou mais o "viver habitualmente" de Salazar, o "não façamos barulho" de António Ferro. A condução da política econômica foi marcada por tantos condicionamentos que seu compromisso com a modernidade era, a meu ver, mais marcado pelas circunstâncias do que propriamente por uma vontade expressa desde o nascedouro do regime. Talvez tenha sido Salazar um reacionário, a conduzir um regime conservador e moderno na perspectiva que afasta o conservadorismo da simples emoção. O Estado Novo, na tradição conservadora de Burke e de Ranke, preocupou-se em manter um aparato jurídico que justificasse as suas ações.

Quanto à sua continuidade do regime no pós-guerra, percebo-a segundo uma perspectiva contrária à de Manuel Loff. Para mim, o pragmatismo de Salazar aliado à distância relativa que manteve com os demais autoritarismos, foi determinante para a sua permanência. Rugas houve, claro está com os 
Aliados em geral e a Grã-Bretanha em particular. Mas foram circunscritas a períodos muito delineados e insuficientes para sequer aproximar da ruptura.

Se o Estado Novo continuou no pós-45, resta saber até que ponto esta continuidade foi acompanhada de maiores ou menores rupturas. Conforme já disse, alguns autores veem-no a partir de algumas importantes quebras. Braga da Cruz, por exemplo, indica cinco fases distintas. Penso, entretanto, na linha apontada por Reis Torgal, que as diferenças são menores que as semelhanças. Mas assim penso não para afirmar a continuidade do fascismo, mas sim de um regime que sequer na "época dos fascismos" foi a meu ver fascista.

Volto, para encerrar este trabalho, ao texto clássico de Manuel de Lucena. Afirma este autor a necessidade de manter o conceito de fascismo para o Estado Novo por que ainda não inventaram outro "deveras sintético e manejável" capaz de garantir seu entendimento ${ }^{109}$. As questões que me passam a partir desta análise são: será que um conceito "sintético e manejável" é eficiente para o entendimento de regimes e realidades tão próprias?; não será a síntese perigosa e empobrecedora diante de fenômenos tão complexos? Talvez "algum" fascismo tenha existido de fato em Portugal. Mas creio que são evidentes outros elementos mais fortes e mais constantes em suas quatro décadas de história: conservadorismo, catolicismo, tradicionalismo agrário...

\section{Bibliografia citada}

ANTUNES, José Freire. Salazar e Caetano: cartas secretas (1932-1968). Lisboa: Difusão Cultura, 1994, p. 112-114; 123.

BENZ, Wolfgang. O nacional-socialismo e o moderno. In: AARÃO REIS, Daniel; MATTOS, Hebe; OLIVEIRA, João Pacheco de; MORAES, Luís Edmundo de Souza; RIDENTI, Marcelo [Organizadores]. Tradições e modernidades. Rio de Janeiro: Editora FGV, 2010, p. 189-200.

BERTONHA, João Fábio. O fascismo italiano e a questão da modernidade: um problema conceitual e político. In: AARÃO REIS, Daniel; MATTOS, Hebe; OLIVEIRA, João Pacheco de; MORAES, Luís Edmundo de Souza; RIDENTI, Marcelo [Organizadores]. Tradições e modernidades. Rio de Janeiro: Editora FGV, 2010, p. 201-216.

BIACHI, Giorgio. Reação. In: BOBBIO, Norberto; MATEUCCI, Nicola; PASQUINO, Gianfranco. Dicionário de Política. $4^{a}$ edição. Brasília, DF: Editora Universidade de Brasília, 1992, p. 10731074. 
BOBBIO, Norberto. O conceito de sociedade civil. $2^{\text {a }}$ edição. Rio de Janeiro: Graal, 1987.

BONAZZI, Tiziano. Conservadorismo. In: BOBBIO, Norberto; MATEUCCI, Nicola; PASQUINO, Gianfranco. Dicionário de Política. 4a edição. Brasília, DF: Editora Universidade de Brasília, 1992, p. $242-246$.

BONIFÁCIO, Maria de Fátima. Historiografia do Estado Novo. In: Estudos de História Contemporânea de Portugal. Lisboa: Imprensa de Ciências Sociais, 2007, p. 93-119.

Sobre o Fascismo e seu advento em Portugal: ensaio de interpretação a pretexto de alguns livros recentes. In: Análise Social. Lisboa: Revista do Gabinete de Investigações Sociais da Universidade de Lisboa. V. XII, N48, 1976, p. 873-915.

Portuguese Fascism in Comparative Perspective. In: $12^{\circ}$ IPSA World Congress. Rio de Janeiro, Agosto de 1982.

BRYMAN, Alan \& BAHER, Peter. Carisma. In: OUTHWAITE, William \& BOTTOMORE, Tom (Editores). Dicionário do pensamento social do século $X X$. Rio de Janeiro: Jorge Zahar Editor, 1996, p. 60-63.

CAETANO, Marcello. A Corporação Universitária. In: A Voz. Lisboa, 30 de março de 1949, p. 1.

COSTA PINTO, António. O Estado Novo português e a vaga autoritária nos anos 1930. In: COSTA PINTO, António \& MARTINHO, Francisco Carlos Palomanes (Organizadores). O corporativismo em português. Estado, política e sociedade no salazarismo e no varguismo. Rio de Janeiro: Civilização Brasileira, 2007, p. 17-43.

O salazarismo e o fascismo europeu: problemas de interpretação nas ciências sociais. Lisboa: Editorial Estampa, 1992.

Os camisas azuis: Ideologia, elites e movimentos fascistas em Portugal 1914-1945. Lisboa: Editorial Estampa, 1994.

CRUZ, Manuel Braga da. O partido e o Estado no salazarismo. Lisboa: Editorial Presença, 1988.

As origens da democracia cristã e o Salazarismo. Lisboa: Presença/Gabinete de Investigações Sociais, 1980 .

As origens da democracia cristã em Portugal e o Salazarismo (I). In: Análise Social. Revista do Gabinete de Investigações Sociais da Universidade de Lisboa. V: XIV. 1978/2 ${ }^{\circ}$ p. $265-278$

As origens da democracia cristã em Portugal e o Salazarismo (II). In: Análise Social. Revista do Gabinete de Investigação Social da Universidade de Lisboa. V: XIV, No 55, 1978/3, 525-607. FERRO, António. Entrevistas a Salazar. Lisboa: Parceria A. M. Pereira, 2007.

HOBSBAWM, Eric. A queda do liberalismo. A era dos extremos. O breve século XX (1914-1991). São Paulo: Companhia das Letras, 1005, p. 113-143.

LEAL, Ernesto Castro. Nação e nacionalismos: a Cruzada Nacional D. Nuno Álvares Pereira e as origens do Estado Novo (1918-1938). Lisboa: Cosmos, 1999.

António Ferro: Espaço Político e Imaginário Social (1918-1932). Lisboa: Cosmos, 1994.

LEVI, Lucio. Regime Político. In: BOBBIO, Norberto; MATEUCCI, Nicola; PASQUINO, Gianfranco. Dicionário de Política. $4^{\mathrm{a}}$ edição. Brasília, DF: Editora Universidade de Brasília, 1992, p.10811084.

LOFF, Manuel. O Nosso Século é Fascista! O Mundo visto por Salazar e Franco (1936-1945). Porto: Campo das Letras, 2008. 
LUCENA, Manuel de. A evolução do sistema corporativo português. Volume I: O Salazarismo. Lisboa, Perspectivas e realidades, 1976.

MARTINHO, Francisco Carlos Palomanes. A ordenação do trabalho e a nostalgia do Império: o Estado Novo português e as razões do consentimento (1933-1974). in: ROLLEMBERG, Denise \& QUADRAT, Samantha (Organizadas). A construção social dos regimes autoritários. Legitimidade, consenso e consentimento no século XX: Europa. Rio de Janeiro: Civilização Brasileira, 2010, p. 283-307.

Entre o fomento e o condicionamento: a economia portuguesa em tempos de crise (19281945). in: LIMONCIC, Flávio \& MARTINHO, Francisco Carlos Palomanes (Organizadores). A Grande Depressão: Política e Economia na Década de 1930 - Europa, Américas, África e Ásia. Rio de Janeiro: Civilização Brasileira, 2009, p. 305-330.

Marcello Caetano et l'espace de la modernité dans l'État Nouveau portugais. In: REIS FILHO, Daniel Aarão \& ROLLAND, Denis (Dir.). Modernités Alternatives: l'Historien face aux discours et représentations de la modernité. Paris: L'Harmattan, 2009, p. 31-46.

. A Bem da Nação: o sindicalismo português entre a tradição e a modernidade (1933-1947). Rio de Janeiro: Civilização Brasileira, 2002.

MARTINS, Hermínio. O Estado Novo. In: Classe, status e poder e outros ensaios sobre o Portugal Contemporâneo Lisboa: Imprensa de Ciências Sociais, 1998, p. 19-51.

Classe, status e poder em Portugal. In: Classe, status e poder e outros ensaios sobre o Portugal Contemporâneo. Lisboa: Imprensa de Ciências Sociais, 1998, p. 99-131.

MARX, Karl. O 18 Brumário de Luís Bonaparte. In: FERNANDES, Florestan (Organizador). MARX/ ENGELS - História. São Paulo: Ática, s/d, p. 280-292.

MEDINA, João. Salazar em França. Lisboa: Ática, 1977.

PATRIARCA, Fátima. A questão social no salazarismo - 1930-1947. Lisboa: Imprensa Nacional/ Casa da Moeda, 1995.

O triângulo corporativo. Acta e encenação de um despacho salarial (1946-47). In: Análise Social. Revista do Gabinete de Investigações Sociais da Universidade de Lisboa. V: XXIII, N 99 , $1987 / 5^{\circ}$, p. $905-944$.

PAXTON, Robert. A anatomia do fascismo. São Paulo: Paz e Terra, 2007.

ROSAS, Fernando. O salazarismo e o homem novo: ensaio sobre o Estado Novo e a questão do totalitarismo. In: Análise Social. Revista do Instituto de Ciências Sociais da Universidade de Lisboa. Vol. XXXV, N 157, p. 1031-1054, 2001.

Salazar e o Salazarismo: um Caso de Longevidade Política. In: ROSAS, F. \& BRITTO, J. M. B. Salazar e o Salazarismo. Lisboa: Dom Quixote, 1989, p. 13-31.

Cinco pontos em torno do estudo comparado do fascismo. In: Vértice. $\mathrm{N}^{\mathrm{o}} 13$. Lisboa, Abril de 1989, p. 21-29.

O Estado Novo nos anos Trinta. 2a Ed. (1928/1938). Lisboa: Estampa, 1986.

SACCOMANI, Edda. Fascismo. In: BOBBIO, Norberto; MATEUCCI, Nicola; PASQUINO, Gianfranco. Dicionário de Política. $4^{\mathrm{a}}$ edição. Brasília, DF: Editora Universidade de Brasília, 1992, p. 466-475. SANDRE, Ítalo de. Carisma. In: BOBBIO, Norberto; MATEUCCI, Nicola; PASQUINO, Gianfranco. Dicionário de Política. $4^{\mathrm{a}}$ edição. Brasília, DF: Editora Universidade de Brasília, 1992, p. 149-151. 
SANTOS, Boaventura de Souza. A crise e a reconstrução do Estado em Portugal. Pensamiento Iberoamericano. Madrid, $n^{\circ}$ 5, Enero-Julio 1984.

SÉRGIO, António. Introdução Geográfico-Sociológica à História de Portugal. $3^{a}$ edição. Lisboa: Clássicos Sá da Costa, 1976.

SHORSKE, Carl E. Da cena pública ao espaço provado: a arquitetura como crítica cultural. Pensando com a história: indagações na passagem para o modernismo. São Paulo: Companhia das Letras, 2000, p. 179-194.

TEIXEIRA DA SILVA, Francisco Carlos. Os fascismos. In: REIS FILHO, Daniel Aarão; FERREIRA, Jorge; ZENHA, Celeste. O Século XX. Volume 2: O tempo das crises: Revoluções, fascismos e guerras. Rio de Janeiro: Civilização Brasileira, 2000, p. 109-164.

Introdução. In: TEIXEIRA DA SILVA, Francisco Carlos; MEDEIROS, Sabrina Evangelista; VIANNA, Alexander Martins. Dicionário crítico do pensamento da direita: Ideias, Instituições e Personagens. Rio de Janeiro: Mauad/FAPERJ, 2000, p. 11-21.

TEIXEIRA DA SILVA, Francisco Carlos \& SCHUSTER, Karl. Figura esvaziada de Hitler. In: Revista de História. Endereço eletrônico: http://www.revistadehistoria.com.br/secao/artigos/figura-esvaziada-de-hitler Acesso em 17 de junho de 2011.

TORGAL, Luís Reis. Estado Novo e fascismo. In: Estados Novos Estado Novo. Coimbra: Imprensa Universidade de Coimbra, 2009, p. 289-367.

TRENTO, Angelo. Fascismo Italiano. São Paulo: Ática, 1986.

VVAA. O fascismo em Portugal. Actas do Colóquio realizado na Faculdade de Letras de Lisboa em Março de 1980. Lisboa: A Regra do Jogo, 1982.

WEBER, Max. Economia y sociedad. México: Fondo de Cultura Económica, 1992. 